\title{
THE ROLE OF JUDAISM IN THE JEWISH COMMUNITY AFTER THE HOLOCAUST ${ }^{1}$
}

\author{
Peter SALner \\ Institute of Ethnology of the Slovak Academy of Sciences \\ Klemensova 19, 81364 Bratislava 1, Slovakia \\ E-mail: evapetersalner@gmail.com
}

\begin{abstract}
Through conflicts of opinions inside the Bratislava Jewish religious community, the author monitors changed relations toward Judaism after the Holocaust.

The current form of the community was due to Regulation 231-1945 concerning "the arrangement of the conditions of the Jewish faith members in Slovakia". This resulted in religious, economic, and organizational centralization.

After the 1968 occupation, those who stayed behind in Bratislava concluded that due to the emigration of the young and middle generations, the community lost its future and under the newly established conditions it was losing its past too. The Velvet revolution helped to overcome passivity existing until then. An informal gathering called Jewish forum helped to build and revive the Jewish identity. The status of the present-day Judaism can be illustrated by the fact that 36.6 percent of funerals in the course of 2001-2013 were done by cremation prohibited in Orthodox Judaism. It has been a manifestation of solidarity with the "burials" of those killed in concentration camps; but it is also a kind of revolt against God who did not prevent the Shoa.

Today both individuals and families create their own model based on the traditions that they choose for themselves. Practicing such customs does not follow from Judaism, but it is an expression of one's affiliation with the community and its traditions.
\end{abstract}

Keywords: Judaism, conflicts inside community, emigration, Jewish forum, identity, cremation

The study focuses on the role that Judaism has played in the Jewish religious community (ŽNO) in Bratislava after the Holocaust. This question seems to be absurd, but it, in fact, reflects changes in social values in Bratislava known as the "Jewish Jerusalem" in the past. This flattering nick-name was mainly due to a prominent rabbi Chatam Sofer living in the $19^{\text {th }}$ century. He and four generations of his descendants (son Ketab, grandson Shevet, great grandson Akiba, and Samuel Schreiber) held the chief rabbi's office continuously from 1806 to 1942 . Akiba Schreiber with his family fled to Palestine; he was

${ }^{1}$ The study was written within the VEGA 2/0024/14 grant entitled Civic Activities as a Determining Factor for the Sustainable City Development. 
followed later on by his son Samuel together with his family. The Sofer family members saved their lives; however, they had to leave behind their leading position in the Bratislava Jewish community. That underwent a radical transformation too.

My study is based on the minutes and other documentation from the ŽNO archives, on professional literature and memoirs. As yet unpublished manuscript of Benjamin Eichler, who served as an official of the Federation of the Jewish Communities (UZŽNO) and of the ŽNO Bratislava for three decades, was another important source of information for me. I was also drawing from Miloš Žiak's books, ${ }^{2}$ which offer rather interesting, though controversial, facts about the post-November 1989 period. The results of the longterm research on the Bratislava Jewish community were published in two monographs ${ }^{3}$ and in several other studies. The topic of this study allows me to take some distance and approach the gathered material in a different way.

I will attempt to present the post-Shoa processes based on the conflicts of ideas inside the community. They can best illustrate the gradual change of the role of religion. At the turn of the forties and fifties there was a dispute between the Orthodox and Neolog Jews, which was later transformed into a conflict of believers versus secular members of the ŽNO. After 1989 it was turned into a conflict of the "Old" versus "New" Jews. These changes have been most evident on the diverse forms of burials of the ŽNO members. They reflect a shift from "religious" to "Jewish", often secular, values.

\section{DEMOGRAPHY OF THE COMMUNITY}

I have concentrated on the community status after 1945; however, for better illustration I am including older data concerning the transformation of the demographic structure after WWI. In 1921, 10,973 persons (11.8\%) claimed to be Jewish. According to the 1930 census, 14,882 citizens claimed their Jewish affiliation, i.e. $12.0 \%$ of the Bratislava population. ${ }^{4}$ Ten years later, the number of Jewish population increased slightly to 15,102 and their total proportion in Bratislava dropped to $10.9 \% .^{5}$

After WWII, approximately 3,000 Jews settled in Bratislava; most of them came from various Slovak regions so that they did not constitute autochthonous population. ${ }^{6}$ This number decreased due to "aliya". From 1945 to 1949, approx. 11,500 Jews (more than a third of the community) left Slovakia, out of them 10,500 emigrated to Palestine/Israel. ${ }^{7}$ Evidently, the largest Jewish community in Bratislava lost a great number of its members though there is lack of exact data about it. Based on the report of the then administrative ŽNO employee, the number of registered "family heads" dropped from 1965 until 1970 to 200 from the initial 800. In the beginning of the nineties, the ŽNO had 670 members, in June 2013 it numbered 609 members.

\footnotetext{
$2 \check{Z ̆}_{\text {IAK }} 2003,2012$.

${ }^{3}$ SALNER 2007, 2008.

${ }^{4}$ HromádKa 1933: 195.

${ }^{5}$ LÁRIŠOVÁ 2000: 26.

${ }^{6}$ EICHLER 1972: 71.

${ }^{7}$ Buchler 1998: 74; see also JablonKová 1998.
} 


\section{POST-WAR SITUATION}

The survivors' attitude to life was strongly affected by the death of more than hundred thousand Jews in Slovakia as well as by their own suffering. One part of them (minority) has preserved or even strengthened their Jewish faith. Words of the newly elected chairman of the Orthodox community, Max Weisz, fully illustrate this fact. In his inaugural speech, which he presented 5 days after the liberation of Bratislava, he said: "Torah saved us and it is our sacred task to save Torah now." In my study on the Jewish identity I resumed the contemporary diverse views in the community: "Most Slovak survivors consider the God after the Holocaust to be an abstract or non-existing concept; definitely, it is not the God from the Old Testament, or one of Torah and mitzvot." 9

Naturally, the Orthodox Jews hastened to revive the religious community life. This could be evidenced by the above initial meeting of the Orthodox Jewish worshippers whose only agenda item was "launching the operation of the autochthonous Orthodox Jewish religious community in Bratislava". It was not only a formal declaration, because the officials reiterated, both orally and practically, the importance of practicing religion. In May 1945 the ritual bath "mikveh" was reopened, ${ }^{10}$ in June Hermann Kratzer was hired "to teach Hebrew in all schools and educational facilities". The board further approved renewed classes at the Higher rabbinical school (yeshiva), and the operation of Chevra Kadisha (burial brotherhood) and other religious institutions were restored. ${ }^{11}$

\section{EDICT 231/1945 AND ITS IMPACTS}

On September 10, 1945 the Slovak parliament adopted decree 231/1945 on the "adjustment of the Jewish faith status in Slovakia", which significantly affected the future community life. Based on it, a new central organization named the Central Union of the Jewish Religious Communities (UZŽNO) was founded. The Union was supposed to "resolve organizational issues of the Jewish faith so as to satisfy every stream in it and they had to establish local Jewish communities named Jewish Religious Community". As a consequence, the whole community including its religious, economic and organizational parts were centralized. The unified religious communities were subordinated to the Central Union (UZŽNO), but both UZŽNO and the local Jewish communities (ŽNO) were controlled by the state. After 1948, the Communist regime banned all other Jewish organizations. UZŽNO and local Jewish communities - ŽNO - were the only permitted Jewish organizations until 1989. Having no other option, the secular Jews joined them too.

However, the leading Orthodox officials did not accept the merger of all communities. Already on August 18, 1945, (i.e. prior to the official announcement), they openly declared their disapproval and lack of interest in cooperation with other streams of Judaism.

\footnotetext{
${ }^{8}$ Minutes of the ŽNO, April 9, 1945.

${ }^{9}$ SAlner 2010: 133.

${ }^{10}$ Minutes of the ŽNO, May 16, 1945.

${ }^{11}$ Minutes of the ŽNO, June 11, 1945.
} 
Following lengthy discussions and disputes, in August 1946 the official elections of the board members of the "unified community" were held. Alexander Pressburger, who ranked among the prominent personalities of the Orthodox judaism, illustrated the overall situation in his introductory speech stressing that "during the whole time when he was heading the religious community, he had attempted to bring the diverse religious groups to one table; however, his effort failed and therefore the Jewish community was left without a real leader". Then A. Pressburger "presented a list of persons who were supposed to be elected to the board and he asked the gathered community members to elect them by acclamation". In the end, 35 new board members were elected together with 13 alternates, but disputes did not end: "After the elections, Dezso Reisner submitted a proclamation on behalf of Aguda saying that Aguda decided to cooperate with others only in the current situation, but it will continue to strive for an independent Orthodox organization." 12

B. Eichler joined initially those who rejected the decree, however, he changed his position later on: "The idea of preserving Judaism may be legitimate and appealing in a democratic society where the Jews of different denominations separate themselves from one another, regardless whether they are ultra-Orthodox, Orthodox, Chasids, Conservative, Neolog, or Reform - all of them have positive attitude to Judaism; however, this is unacceptable in a country, the official policy of which rejects any religion. Such situation requires joint efforts aimed at preserving Judaism." Orthodox Jews continued to dominate the newly established communities too. The story of cantor Samuel Landerer illustrates it. This pious man could not lead prayers in the Heydukova Orthodox temple, "just because he had held services for Neolog Jews at the time when one could hardly speak about the existence of the Orthodox Jewry in Bratislava and when the so-called Orthodox members did not have their own cantor". ${ }^{13}$ Thus, he decided to move to the Czech Republic in 1954 where he served in several towns. After 10 years he got an offer to return to Bratislava: "We learned that the chief cantor of Prague, S. Landerer is retiring. Dr. Eichler suggested that we get in touch with him and invite him back to Bratislava in order to lead holiday prayers and make public appearances. The board accepted the proposal."'14 Landerer rejected the offer and left for Israel in 1964. The offered hand demonstrated a decreasing position of the Orthodox Jewry and also a gradual drop of tension among diverse streams of Judaism. Reconciliation between the Orthodox and Neolog believers was due to the changes of the "demographic structure" of the community. The 1954 elections of the community board members manifested a growing influence of the secular community members. There appeared a conflict between the secular and practicing religious members (regardless whether they were Orthodox or Neolog). At the same time, it was a struggle for the future character of the Jewish community. According to the valid bylaws, "only a morally spotless, politically reliable man, who was loyal to the people and the people's democratic establishment of Czechoslovakia and who observed the Jewish religious regulations" could be considered as a future board member. Following the latter, the chief rabbi Eliáš Katz protested that "among the newly elected board members

\footnotetext{
${ }^{12}$ Minutes of the ŽNO meeting, August 8, 1946.

${ }^{13}$ Eichler 1972: 75.

${ }^{14}$ Minutes of the ŽNO, December 15, 1963.
} 
one could identify people who are not suitable" (i.e. they do not observe religious regulations). The resolution of the dispute was decisive for the future, i.e. who will dominate the board - rabbis or secular members who got majority votes from their supporters. ${ }^{15}$ In the end, it was decided that "every person claiming his/her Jewish faith, whether practicing religion or not, is entitled to exercise all the rights of the ŽNO provided that all other conditions of the elections rules were satisfied"16. Consequently, the secular position, which reflected the actual community situation, prevailed.

Spiritual leaders continued to enforce their priorities. The center of attention was shifted to the draft bylaws that delegates of the General assembly of the Jewish Religious communities should have passed in 1955. It was again Benjamin Eichler, who sharply criticized rabbi Katz's views: "Prior to the assembly the commission gathered to draft bylaws. A fierce fight broke out between the three practicing rabbis and secular members, but particularly between rabbi Katz on the one hand and the communities reps on the other. Katz attempted to gain control over the secular community group, which would resemble the Catholic Church structure and which would contradict the Jewish traditions." 17

Even though one part of the Jewish community strove to attract younger generations to religious services, their attempts failed. After all, young people continued to show less and less interest in religion, also thanks to pressures made by the contemporary regime and schools. Eichler noted that if parents enrolled their children in religious classes, their school teachers tried to discourage them. He held the parents responsible for this, because, in his view, they not only gave in to external pressures, but also to the rabbis who "for their most part paid little attention to the youth, failed to teach them to pray, or to acquaint them with basic principles of Judaism; thus a considerable part of the young generation was brought up in ignorance of the Hebrew, they were unable to pray and demonstrated lack of interest in Judaism as a whole". According to Eichler all this was due to "unjustified lack of courage". 18

The 1968 military invasion resulted in a mass emigration of the community members. As a result, the remaining members in Bratislava gave way to resignation: "It did not matter who held the leading posts in the community, because it was a long-term phenomenon. They realized clearly that the community lost its future when a large part of the young and middle generation members left and due to the newly established political system it was losing its past too." 19 Under the normalization period (1970-1989) the community focused only on religious and social activities. Its officials managed to ensure regular religious services, though during the years of 1978-1993 there was no rabbi in Bratislava (nor in the rest of Slovakia). Religious services were conducted by the elder community members. Some of them attended yeshiva in their youth, others learned about religion at home. Practicing members could also get kosher meals. The community leaders organized celebrations of the Jewish holidays like Purim, Passover, Hannukah. Ritual slaughtering of poultry continued, a "shoychet" was

\footnotetext{
${ }^{15}$ EICHLER 1972: 4.

${ }^{16}$ Minutes from the UZŽNO session, November 14, 1954.

${ }^{17}$ EICHLER 1972: 4-5.

${ }^{18}$ EICHLER 1972: 11.

${ }^{19}$ SAlner 2008: 156.
} 
arriving from Hungary for ritual slaughter of the cattle. "Apathy united" the whole community during that time. There occurred personal conflicts from time to time, but no religious disputes.

\section{THE JEWISH COMMUNITY (ŽNO) AFTER NOVEMBER 1989}

Inactivity ended after the November 1989 revolution. Glimps of contemporary atmosphere is provided by Miloš Žiak: "The Bratislava Jewish community was filled with turmoil. A so-called 'Jewish forum' was founded in the old run-down kosher canteen located under the castle hill. The name 'forum' was adopted from the contemporary call of the Coordinating Center of the Public against Violence reps who appealed to the public to initiate and establish alternative platforms (both professional and leisure-time forums) which should serve as informal civic associations representing citizens' views with respect to the government. The Jewish forum was managed by a group of forty-yearold members headed by Pavel Traubner. Traubner and Stern could describe the forum beginnings the best; for the first time, I was introduced to it by Juraj Reich, who was invited to the forum to speak about UZŽNO activities by 'new Jews' (as Reich referred to them). Most of them were assimilated Jews whose aim was not to revive the religious institutional foundations of the community (ŽNO), but rather to unify the Slovak Jewish people on the basis of their common historical and cultural backgrounds and, in particular, on remembering the joint experience of the Holocaust. The chairman of the UZŽNO, Bedrich Grunwald, who was old and ill, was quietly pushed away into forgetfulness. Juraj Reich took the initiative on behalf of UZŽNO, because he realized the threat of a possible split in the Slovak Jewry; we discussed it many times before. Reich was ready - also thanks to my encouragement - to search for a way of compromise. He was willing, though not excited about it, to provide space to the assimilated Jews under the umbrella of the Orthodox religious community. It was a kind of paradox when the official positions in the religious community were taken by people, whose attitude to religion was rather distant, if not entirely alien. The Jewish forum was attended by members or no-members of the Bratislava ŽNO, by Orthodox and assimilated Jews, respectively, who would not qualify as Jewish even by the most liberal criteria. The assimilated Jews attempted to transfer this 'mixture' from the Jewish forum to the Jewish community too, in order to ensure that the most numerous secular group could also be represented there; however, they met with severe resistance. In terms of the future, Reich played undoubtedly a positive role in bringing together diverse Jewish groups and individuals as he kept stressing that the Jewish religious community represents the interests of the practicing Jews and it should strive to preserve and strengthen the religious identity of the Slovak Jews. Though I was one of the assimilated Jewish members, I openly supported Juraj Reich's efforts. Also thanks to my status of a member of the Coordinating Center of the Public against Violence (KV VPN), I helped to block attemps at 'crushing down' the existing religious community foundations of the Slovak Jewry."20

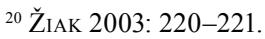


The above quotation refers to the contradiction between the "old" and "new" Jews that Žiak does not quite precisely interprete as a conflict between the practicing (in his view solely Orthodox) and assimilated Jews. (It is a paradox though that Žiak himself belongs to the group of "the new" Jews). The official affiliation with Judaism was only a secondary criterion for the community members. They perceived those, who under Socialism claimed to be Jewish, attended the Ž $\mathrm{NO}$ events, and/or the services in synagogues as the "old" Jews; the "new ones" were those who became interested in Judaism only after 1989.

Special attention should be paid to the Jewish forum, which played an important role, though by far not so negative as described by M. Žiak. It was held in the old canteen of the Jewish community - ŽNO - once a month. Particularly in the first months after the Velvet revolution, it significantly helped to shape the identity of the "hesitating" community members, strengthening the "Jewish" confidence. The fact that personalities from social, political and cultural life including guests from abroad participated in the "Jewish gatherings" was of special importance at that time and it went far beyond an enjoyable Friday evening. The quantitative factor reflected in the number of regular participants, who were gradually building or renewing social network, was very positive too. Many of them have remained active ŽNO members until today.

However, "the other side" criticized the fact that the Forum was held on Friday evening, i.e. during the Shabbat services in synagogue. A number of members were leaving earlier to be able to attend the Forum; others ignored it to express their disapproval. (Under the pressure of the new community management, the organizers shifted it to Sunday, which resulted in a marked drop of attendance. It could have been caused also by the fact that the social situation became more stable and there emerged other Jewish events so that the Forum stopped to be the only Jewish attraction). Žiak in his next book explains why, in his view, the future prospects of the community lie in the Orthodox Judaism: "In spite of resistance of the majority of board members, I made them accept a Lubavich rabbi Baruch Myers, who moved with his family from New Jersey to Bratislava. The arguments of my opponents faithfully reflected the contemporary situation of the Slovak Jewry after six years of fascist rule and subsequently, of forty two years of the Communist government in Slovakia. According to them, the Jews in the post-communist Slovakia reached the irreversible internal split and assimilation so that the arrival of a radically Orthodox Chabad rabbi would only further complicate the situation. I argued that only a radically Orthodox rabbi can, at least partly, set back the disintegration process characterizing the then state of the Jewish life. We will certainly not turn into Orthodox Jews, but it will help to slow down the assimilation process, our children will receive Jewish religious education so that as soon as they become adults, they could make their own choice as to their religious affiliation and the way of life."21

Relations in the Jewish community have been further complicated by a continuing tension between the practicing and secular Jews, which the above-mentioned rabbi Baruch Myers reflected too. He took his position on July 1, 1993, i.e. in the most difficult period following the split of Czechoslovakia. Lots of Jews were worried that independent Slovakia might bring back the situation typical for the war-time Slovak republic. Apart from

\footnotetext{
${ }^{21} \check{Z ̆}_{\text {IAK }} 2012: 350$.
} 
the political situation, Myers had to tackle with other handicaps too: "exotic" appearance of the Orthodox rabbi with a quickly growing family, initially insufficient command of the Slovak language, and the fact that he did not come from an environment that had been directly affected by the Holocaust; last but not least, strongly diversified environment in which he began his work. On the day of his arrival, the UZŽNO symbolically opened the General assembly by a common prayer. The last time...

After ten years, Myers evaluated his work in the Jewish community in the following way: "The religion is perceived quite differently by rabbis and the community members. On the one hand, there is the rabbi who believes in Torah as God's word and who practices both oral and written tradition as the God's will. On the other hand, there are the community members, some of whom perceive religion as a set of customs or folklore." ${ }^{22}$ In another ten years, when marking the $20^{\text {th }}$ anniversary of his arrival to Slovakia, he brought up a story about a Jew from Vilnius: "When I was reading this story, it reminded me of our Bratislava Jewish community. A small group of people with very diverse personalities of different setting and attitudes toward religion. Unfortunately, it is impossible to have as many rabbis here as to satisfy everyone. This has not made my work easier in the least in the past twenty years." ${ }^{23}$

\section{JUDAISM AND FUNERAL}

In order to understand the position of Judaism in the studied environment, one has to turn attention to the ways of burial. The last farewell is strictly a family related, intimate ritual that, at the same time, is held before the public eyes. It takes place, therefore, under supervision of the community members, the non-Jewish majority and in some cases (at least this was the case in the near past) under the control of the state power. This fact would influence the way of funeral in the past. There are four alternatives of the funeral that the community members opt for: traditional funeral (Orthodox or Neolog); civil, non-religious ritual; cremation. The burial records in the $21^{\text {st }}$ century have shown decreased interest in the Jewish (religious) forms of funeral. I have available data on 246 ŽNO members who passed away from January 1, 2001 until the end of June 2013. In 90 cases $(36.6 \%)$ there was cremation present, in 127 instances there was a Jewish funeral (63 times Orthodox, 64 times Neolog). In the remaining 29 cases $(11.8 \%)$, the family burried their deceased in non-Jewish cemetery or in some cases the type of funeral was unknown. ŽNO leadership had to consider a high proportion of cremations as well. After long lasting disputes, beginning January 1, 2007, the community members approved the option to have urns placed in a recently constructed columbarium - a wall located outside the burial site, but on the Neolog cemetery grounds. As of today, it contains 32 urns.

Even though cremation is forbidden by the Jewish law, many community members chose it. According to our research, it is mainly due to the Holocaust. It not only reflects solidarity with the fate of the murdered and burnt Jewish people, but also a kind of revolt against the G-d, who allowed Shoa to happen. To a lesser extent there are some other

${ }^{22}$ Myers 2003: 17-18.

${ }^{23}$ Myers 2013: 1. 
factors at play too (atheism, fear of retributions from the Communist regime, attempts at assimilation, etc.). Interestingly enough, both polarized parties of the dispute claim to be Jewish. One perceives jewishness rather ethnically or culturally, while the other religiously. A great number of urns contain the ashes of the people who were cremated in the past. Their families used the new option to place the urns in the Jewish cemetery plot, in spite of increased costs connected with it (they have to cover $180 \%$ of the traditional funeral expenses). ${ }^{24}$

The data gathered in this study show that Judaism plays an important role for the Bratislava $\breve{Z} \mathrm{NO}$, though not a primary one. It is a valid definition that "both individuals and families are creating their own model based on the traditions that they prefer to choose for themselves". ${ }^{25}$ The performing of such selected practices (synagogue attendance during holidays or on Jahrzeit of family members, lighting Shabbat candles, fasting on Yom Kipur, semikosher diet, etc.) is not a religious sign in most cases. This is a form of declaration of one's affiliation with the Jewish community and an expression of respect to its Jewish traditions. However, this approach does not exclude to incorporate non-Jewish elements including cremation that Judaism rejects due to religious reasons. Thus, based on the above gathered facts, it seems fair to state that the present-day attitude to Judaism reflects the community transformation rather than its extinction.

\section{LITERATURE}

BüCHLER, Robert Jehošua

1998: Znovuoživenie židovskej komunity na Slovensku po druhej svetovej vojne. [Revival of the Jewish Community in Slovakia after the WWII.] Acta Judaica Slovaca, 4, 65-78.

EICHLER, Benjamin

1972: Príspevok $k$ histórii Židov na Slovensku z doby druhej svetovej vojny až po október 1972. [On the History of Jews in Slovakia during the WWII until October 1972.] Toronto, 104 pp.

GYARFÁsovÁ, Tína

2008: Faktory intergeneračného prenosu židovskej identity na Slovensku. [Factors of the Inter-Generational Transfer of Jewish Identity in Slovakia]. Sociální studia 5(3-4), 179-192.

HromÁDKA, Jan

1933: Zemepis okresu bratislavského a malackého. [Geography of the Bratislava and Malacky Districts.] Vol.: Bratislava. Bratislava.

JABLONKOVÁ, Chana

1998: Izrael a Židia zo Slovenska. [Israel and the Jews from Slovakia.] Acta Judaica Slovaca 4, $163-186$. JELÍNEK, Jehošua Andrej

2009: Dávidova hviezda pod Tatrami. [David's Star under the Tatra.] Praha: Vydavatel'stvo Jána Mlynárika. LÁRIŠOvÁ, Petra

2000: Židovská komunita v Bratislave v roku 1940. [The Jewish Community in Bratislava in 1940.] Bratislava: The Holocaust Documentation Center.

Myers, Baruch

2003: Problémy pri šírení naboženských hodnôt v Českej a Slovenskej republike. [Problems with Disseminating the Jewish Values in the Czech and Slovak Republics.] In: GÁL, E. (ed.): Židia dnes, Bratislava. [The Jews Today.] ROAD, 13-26.

\footnotetext{
${ }^{24}$ For more details see SALNER 2014.

${ }^{25}$ Gyarfásová 2008: 185.
} 
2013: Prvých dvadsat' rokov. [The First Twenty Years.] Bratislava Kile 9(3), 1, 8.

SALNER, Peter

2000: Židia na Slovensku medzi tradíciou a asimiláciou. [The Jews in Slovakia between Tradition and Assimilation.] Bratislava: Zing Print.

2007: Mozaika židovskej Bratislavy. [Mosaic of the Jewish Bratislava.] Bratislava: Marenčin PT.

2008: Premeny židovskej Bratislavy. [Transformations of the Jewish Bratislava.] Bratislava: Marenčin PT.

2010: The Holocaust and the Jewish Identity in Slovakia. Pardes, Zeitschrift der Vereinigung fur judische Studien Heft 16, 117-133.

2014: Požehnaný spravodlivý sudca. Súčasné formy židovského pohrebu [Blessed in the Judge of Truth. ŽIAK, Miloš The Present-day Forms of Jewish Funeral]. Bratislava Zing Print.

2003: Mrzáci studenej vojny. [The Cold War Cripples.] Bratislava: Kalligram.

2012: História môjho holubnika. [My Dovecot History.] Bratislava: Kalligram. 